\title{
THE IMPACT OF THE APPLICATION OF BREWER'S BY-PRODUCT ROASTED BARLEY HUSKS ON SELECTED PARAMETERS OF RUMEN FERMENTATION OF DAIRY COWS. IN VITRO STUDY
}

Department of Cattle Breeding and Milk Production, Institute of Animal Breeding, Wroclaw University of Environmental and Life Sciences, Poland

${ }^{1}$ Department of Animal Physiology and Biostructure, Institute of Animal Physiology, Wroclaw University of Environmental and Life Sciences, Poland

\begin{abstract}
The aim of the study was to evaluate the effect of brewer's by-product roasted barley husks additive (RBH) on the cow's rumen fermentation process, in in vitro conditions. Ruminal fluid for the research was collected from 9 dairy cows selected on the basis of analogues. Animals were fed total mixed ratio (TMR). The substrates for in vitro experiment were composed on the basis of TMR. Control substrate contained only TMR. Substrates D1, D2, D3 contained TMR with the addition of respectively: 5,10 and $15 \%$ of dry matter of RBH. Substrate D4 contained only RBH. Samples of ruminal fluid were incubated for 8 hours, in anaerobic conditions, at $39^{\circ} \mathrm{C}$. A desirable effect of applying RBH was observed in groups D3 and D4 the production of volatile fatty acids (VFA) increased. Furthermore, positive effects were observed in groups D2 and D4 - acetic acid production decreased (by up to 7\%). Reduced methane production (up to 10\%) was observed in experimental groups which indicates that animals would have smaller energy losses. Most beneficial changes in the VFA profile and the highest growth of non-glucogenic and glucogenic acids ratio (NGR) were recorded in D3 group samples. Positive results in this matter are promising as the roasted barley husks are a by-product of beer production and its usage has both economic and ecologic benefits. Obtained results in the in vitro study are the prerequisites to carry out an in vivo experiment.
\end{abstract}

Key words: barley husks, microbial fermentation, rumen, methane, volatile fatty acids.

\section{INTRODUCTION}

Beer produced on the basis of barley grain was already known in Egypt 5000 years before common era (Cabras and Higgins 2016). Currently the roasted barley is used in the manufacture of very dark beers, such as Porter, Stout or Dark Beer. About $10 \%$ of grains used in the beer production are barley. Grain for beer manufacturing is processed by roasting the crude grains at a temperature of approx. $200^{\circ} \mathrm{C}$. Roasted barley grain can also be used as an addition to coffee (Dłużewski 2001). The roasted barley husks are a by-product of the roasting process of barley (Urbaniak and Błędzki 2015).

Corresponding author: Rachela Anna Formella, Department of Cattle Breeding and Milk Production, Institute of Animal Breeding, Wroclaw University of Environmental and Life Sciences, Józefa Chełmońskiego 38c, 51-630 Wrocław, Poland, e-mail: Rachela.Formella@up.wroc.pl, ORCID: 0000-0002-7042-6547 
Production of beer in Europe and Central Asia amounts 72 million tons per year, and in Poland alone, 3.8 million tons (FAO 2014). By-products constitute approx. 20\% of the beer production. Spent grain, mainly consisting of husks, makes $85 \%$ of those by-products (Gupta et al. 2010). Barley husks based brewing by-products can be used, inter alia, as an additive in animal and human nutrition (Mussatto et al. 2006; McCarthy et al. 2012), for the production of biogas as a source of energy (Zanker and Kepplinger 2002), for the manufacture of carbon (Sato et al. 2001; Okamoto et al. 2002), for the manufacture of paper (Ishiwaki et al. 2005) and in the biotechnology (Mussatto et al. 2006).

The high content of crude fibre and crude protein make the spent grain (which consists mostly of barley husks) an excellent addition to the diet of dairy cows (Mussatto et al. 2006). Other authors studied the nutritional value of brewing by-products consisting mainly of barley husks (Davis et al. 1983; Mussatto et al. 2006; McCarthy et al. 2012). Results of their studies are the reason to research the effect of adding $\mathrm{RBH}$ to TMR on cow's rumen fermentation profile. In the available literature no research describing the influence of roasted barley husks on rumen fermentation has been found. Such research is important because rumen fermentation processes influence the health of animals and the quality of animal products.

The aim of this study was to evaluate the effect of roasted barley husks additive (brewing by-product) on the cow's rumen fermentation process, in in vitro conditions.

\section{MATERIAL AND METHODS}

\section{Animals and ruminal fluid}

The ruminal fluid used in the research was collected using a probe (Basko) from nine cows of the Polish Holstein-Friesian breed. Animals for the experiment were selected by analogy for age (second lactation), stage of lactation (peak lactation, 40th-50th day) and condition (3.5 points in Body Condition Score - BCS) (Edmonson et al. 1989). All of the animals were kept in the tie stall barn and fed TMR composed of: corn silage $56 \%$, spent grain $21 \%$, grass silage $13 \%$, straw $4 \%$, dried beet pulp $2 \%$ and $4 \%$ balanced concentrate.

\section{Analysis of feeding components}

A comprehensive analysis of the composition was made (apparatus NIRS DS 2500, FOSS) for roasted barley husks, TMR and TMR components: grass silage and corn silage. Following feeding components of substrates were analyzed: dry matter (method 934.01 of AOAC 2005), crude ash (method 942.05 of AOAC 2005), crude protein (Kjeldahl method, method 984.13 of AOAC 2005 using a conversion rate $N \times 6.25$ ), crude fat (method 920.39 of AOAC 2005), crude fibre (method 978.10 of AOAC 2005), neutral-detergetnt fibre - NDF (method of Holst, 1973), acid-detergent fibre - ADF (method 973.18 of AOAC 2005) and starch (method 996.11 of AOAC 2005). Feed unit for lactation (UFL) was determined. Results are presented in Table 1. The diet of cows was arranged according to the French standard INRA (IZ-INRA 2009). 
Table 1. The chemical composition of fresh forage [\%] used to make substrates for in vitro experiment

\begin{tabular}{lrccc}
\hline Item & TMR & Roasted barley husks & Grass silage & Corn silage \\
\hline Dry matter & 35.14 & 90.67 & 35.40 & 40.18 \\
Crude ash & 2.80 & 10.56 & 9.35 & 6.05 \\
Crude protein & 5.29 & 25.96 & 15.88 & 6.03 \\
Crude fat & 1.14 & 1.72 & 3.60 & 3.55 \\
Crude fibre & 6.62 & 14.11 & - & - \\
NDF & 14.56 & 74.82 & 51.98 & 38.71 \\
ADF & 8.34 & 37.49 & 32.07 & 23.65 \\
Starch & 9.63 & 6.93 & 0.00 & 32.42 \\
\hline
\end{tabular}

The substrates for in vitro experiment were composed on the basis of dried TMR ingredients. Control substrate (C) contained only TMR. Substrates D1, D2, D3 contained the same components as the control substrate, but with the addition of 5,10 and $15 \%$ of dry matter of roasted barley husks. The last substrate D4 contained only roasted barley husks. The composition of substrates used in experiment is presented in Table 2.

Table 2. The chemical composition of substrates (in \% of dry matter) for in vitro experiment

\begin{tabular}{lccccc}
\hline \multicolumn{1}{c}{ Item } & C (only TMR) & $\begin{array}{c}\mathrm{D} 1 \text { (TMR + 5\% } \\
\text { roasted barley } \\
\text { husks) }\end{array}$ & $\begin{array}{c}\mathrm{D} 2 \text { (TMR + 10\% } \\
\text { roasted barley } \\
\text { husks) }\end{array}$ & $\begin{array}{c}\mathrm{D} 3 \text { (TMR + 15\% } \\
\text { roasted barley } \\
\text { husks) }\end{array}$ & $\begin{array}{c}\mathrm{D} 4 \text { (only roasted } \\
\text { barley husks) }\end{array}$ \\
\hline Dry matter [\%] & 92.21 & 90.80 & 90.88 & 90.59 & 90.67 \\
Crude ash & 9.48 & 10.35 & 10.50 & 10.39 & 10.56 \\
Crude protein & 11.16 & 16.95 & 15.66 & 16.72 & 25.96 \\
Crude fat & 0.72 & 0.78 & 0.82 & 0.91 & 1.72 \\
Crude fibre & 22.95 & 14.71 & 16.99 & 15.83 & 14.11 \\
Starch & 9.80 & 9.67 & 9.44 & 9.29 & 6.93 \\
\hline
\end{tabular}

Fermentation in vitro. Samples of ruminal fluid were collected two hours after the morning feeding of the animals and transported to the laboratory at the temperature of $36-39^{\circ} \mathrm{C}$. The obtained samples of ruminal fluid were filtered through surgical gauze, partitioned into $20 \mathrm{ml}$ portions and poured to serum bottles with a capacity of $125 \mathrm{ml}$ (Sigma-Aldrich). To each bottle the appropriate buffer was added in an amount of $60 \mathrm{ml}$ to dilute the content (McDougall 1948). The samples were divided into five groups and incubated with $1 \mathrm{~g}$ of the prepared substrate. Serum bottles were thoroughly flushed with carbon dioxide to obtain anaerobic conditions and hermetically sealed with a manual crimper. Samples were incubated for 8 hours of in vitro fermentation in a shaking water bath at $39^{\circ} \mathrm{C}$.

\section{Analysis of selected products of fermentation}

After incubation, the headspace pressure was measured in each bottle. Methane content in the gas was measured through gas chromatography (Agilent Technologies $7890 \mathrm{GC}$ System, Santa Clara, USA). The chromatograph was equipped with a flame ionisation 
detector (FID), thermal conductivity detector (TCD), two Supelco columns HayeSep $Q$ and Porapak Q (Supelco, Bellefonte, USA), as well as a 5A Molecular Sieve. Helium was used as the carrier gas with flow rate: $0.42 \mathrm{ml} / \mathrm{s}$.

The liquid samples had $\mathrm{pH}$ measured (CP-401 pH-meter Elmetron with an EPP-3 electrode and temperature sensor), then the samples were centrifuged and formic acid was added $(0.1 \mathrm{ml}$ of formic acid per $2 \mathrm{ml}$ of sample) to stop fermentation. Gas chromatograph (Agilent Technologies 7890 GC System) with FID detector and column (DB-23, Agilent J\&W) with helium as the carrier gas (flow rate $25 \mathrm{ml} / \mathrm{min}$ ) was used to indicate total concentration of VFA and the percentage of individual acids: acetic, propionic, isobutyric, butyric, isovaleric, valeric and caproic. Peak identification of volatile fatty acids was carried out by comparing the retention times to standards supplied by Sigma (Free Acid Mix Supelco).

\section{Calculations and statistical analysis}

Mutual relations were calculated between acids: acetic acid and propionic acid (A : $P)$, propionic acid and butyric acid ( $\mathrm{P}: \mathrm{B})$. Utilization rate of VFA was calculated by expressing the ratio of non-glucogenic acids to glucogenic acids (NGR) according to the following formula:

$N G R=(A+B 2+P c) /(P+P c)$

$A, P, B, P c$ is respectively: acetic acid, propionic acid, butyric acid, and valeric acid in mol\% in the total VFA volume (Abrahamse et al. 2008). Nine samples were analyzed in each experimental group with the specific substrate (C, D1, D2, D3, D4). Therefore a total of 45 samples of rumen gastric juices were analyzed.

The test results were statistically compiled through a one-way analysis of variance (ANOVA) using a computer program Statistica 10.0. Differences were considered at the significance level of $P<0.185$ using Duncan's new multiple range test for five groups. In the range of $0.05<\mathrm{P}<0.1$ statistical trend was additionally estimated and analyzed.

\section{RESULTS}

Profile of VFA in fresh ruminal fluid (Table 3) was characterized by the highest share of acetic acid, lower of propionic acid and the lowest of the butyric acid when compared to the values presented in Table 4. In the general pool of these three major VFA, observed molar proportions were $58: 28: 14$ (acetic : propionic : butyric). Measured proportions indicate normal physiological processes in samples collected from all cows. After 8 hours of fermentation with the addition of substrates (Table 4), increase in acetic acid and propionic acid and a slight decrease in the share of butyric acid were observed. Production of isobutyric acid in groups D2 and D4 decreased.

In analyzed samples (Table 4) from the rumen, after 8 hours in vitro fermentation, the $\mathrm{pH}$ level stayed between 6.09 and 6.14 in four research groups (D1, D2, D3 and D4) and only in the control group (C) fell below 6 and averaged at 5.97. The metabolic energy for TMR was 11.5 MJ EM, while for the roasted barely husks 9.5 MJ EM.

Fermentation indicator calculated on the basis of the level of VFA (P : B) implies a reduction of butyric acid, especially in D3 group (Tables 3 and 4). Improvement in results was observed with increased amount of roasted barley husks added to TMR. 
Table 3. Fermentation profile of fresh ruminal fluid after adding the buffer

\begin{tabular}{lcc}
\hline \multicolumn{1}{c}{ Fermentation parameters } & Fresh ruminal fluid & SEM \\
\hline $\mathrm{pH}$ & 7.91 & 0.168 \\
SCFA $^{\mathrm{a}}$ & 89.78 & 8.669 \\
Acetate $^{\mathrm{b}}$ & 54.49 & 2.923 \\
Propionate $^{\mathrm{b}}$ & 26.39 & 1.871 \\
Isobutyrate $^{\mathrm{b}}$ & 2.01 & 1.045 \\
Butyrate $^{\mathrm{b}}$ & 13.64 & 1.493 \\
Isovaleriate $^{\mathrm{b}}$ & 2.30 & 0.397 \\
Valeriate $^{\mathrm{b}}$ & 1.09 & 0.589 \\
Caproate $^{\mathrm{b}}$ & 0.08 & 0.036 \\
$\mathrm{~A}: \mathrm{P}^{\mathrm{b}}$ & 2.20 & 0.246 \\
$\mathrm{P}: \mathrm{B}^{\mathrm{b}}$ & 2.09 & 0.227 \\
NGR & 2.91 & 0.293 \\
\hline
\end{tabular}

SCFA - short chain fatty acids.

${ }^{a} \mathrm{mmol} / \mathrm{kg}$ of undiluted ruminal content.

${ }^{\mathrm{b}}$ percentage in the total molar concentration of SCFA [mol \%].

Table 4. Changes in ruminal parameters after 8 hours in vitro fermentation

\begin{tabular}{|c|c|c|c|c|c|c|c|}
\hline $\begin{array}{l}\text { Fermentation } \\
\text { parameters }\end{array}$ & C & D1 & D2 & D3 & D4 & SEM & P-value \\
\hline $\mathrm{pH}$ & 5.97 & 6.14 & 6.13 & 6.09 & 6.11 & 0.051 & 0.849 \\
\hline SCFA ${ }^{a}$ & 187.86 & 148.56 & 184.68 & 208.83 & 211.19 & 12.156 & 0.516 \\
\hline Acetate $^{b}$ & 42.46 & 49.34 & 41.09 & 52.63 & 39.49 & 2.159 & 0.120 \\
\hline Propionate ${ }^{b}$ & 42.83 & 38.02 & 46.61 & 37.81 & 46.45 & 1.852 & 0.293 \\
\hline Isobutyrate ${ }^{b}$ & 0.41 & 0.48 & 0.20 & 0.00 & 0.29 & 0.079 & 0.376 \\
\hline Butyrate ${ }^{b}$ & 11.86 & 9.38 & 10.21 & 7.12 & 10.16 & 0.694 & 0.300 \\
\hline Isovaleriate ${ }^{b}$ & 1.51 & 1.75 & 0.76 & 1.83 & 2.04 & 0.233 & 0.484 \\
\hline Valeriate ${ }^{b}$ & 0.76 & 0.42 & 1.02 & 0.43 & 1.48 & 0.137 & 0.062 \\
\hline Caproate $^{b}$ & 0.18 & 0.02 & 0.10 & 0.18 & 0.09 & 0.035 & 0.540 \\
\hline$A: P^{b}$ & 1.13 & 1.43 & 0.94 & 2.34 & 0.95 & 0.238 & 0.332 \\
\hline$P: B^{b}$ & 4.05 & 1.43 & 4.38 & 6.15 & 5.09 & 0.319 & 0.176 \\
\hline NGR & 1.65 & 1.76 & 1.33 & 2.67 & 1.35 & 0.229 & 0.369 \\
\hline Gas production a & 3.24 & 3.27 & 3.35 & 3.22 & 3.25 & 0.167 & 1.000 \\
\hline Methane $^{a}$ & 1.14 & 1.03 & 1.09 & 1.07 & 1.05 & 0.054 & 0.339 \\
\hline
\end{tabular}

SCFA - short chain fatty acids.

a $\mathrm{mmol} / \mathrm{kg}$ of undiluted ruminal content.

${ }^{\mathrm{b}}$ percentage in the total molar concentration of SCFA [mol \%]. 


\section{DISCUSSION}

According to research done by Deepak et. al. (2013), barley husks consist of $39 \%$ cellulose, $12 \%$ hemicellulose, $22 \%$ lignin, $11 \%$ starch, $4 \%$ protein and $4 \%$ fat. Roasted barley husks used in this study had different parameters. The biggest difference was observed in protein content - almost $26 \%$ in our husks (Table 1). The research shows that the irrigation level of barley cultivations does not affect the composition of the barley husks but early planting date may result in a higher content of lignin (Grove et al. 2003). More important, however, is the absorption of water by the whole seeds, grain endosperm and the husk of barley. The research on this matter helps to facilitate and reduce the cost of analysis of barley grains intended for brewing while improving the production (Cozzolino et al. 2015). Ferulic and p-coumaric acids are primary coreless phenolic lignins (Moore and Hatfield 1994). The level of lignin and acid content of p-coumaric in husks of barley are rising along with ripening of plants while the level of ferulic acid remains constant (Grove et al. 2003).

Rumen fermentation requires adequate and stable physicochemical conditions. One of them is the $\mathrm{pH}$ of which optimal value is from 6.2 to 6.7 (Abdel Hameed et al. 2013). The pH of the ruminal fluid depends largely on the time of feeding and the type of forage given to cows (Křižova et al. 2011). Decrease of pH level below 6 results in reduced VFA production (Bhatta et al. 2006). In our study, the pH level after fermentation stayed at a desirable level (above 6) for all research groups containing roasted barley husks (D1, D2, D3, D4).

VFA produced in the process of microbial fermentation in the rumen are a source of energy. Their levels and composition depend primarily on the diet (Morvay et al. 2011). In addition to the content of individual fatty acids, their relative proportions are also important. It is assumed that the ratio of acetic to propionic to butyric acids should be around $77: 15: 8$ (Zhou et al. 2012) before rumen fermentation in vivo begins. The proportions of VFA most similar to the literature data (Zhou et al. 2012) were achieved in our research in samples with the addition of $15 \%$ of roasted barley husks (D3) - $54: 39: 7$ (acetic : propionic : butyric).

VFA covers approx. $80 \%$ of the energy needs of the animals (Heinhrisch and Varga 1996). Along with the increase of VFA production, milk yield increases (Piva et al. 1993). Therefore, an increase of VFA production in groups D3 and D4 from our study is beneficial. Levels of NDF and ADF reported for barley husks were consistent with Grove's studies (Grove et al. 2003), but higher than earlier research results (Bell and Keith 1988). Increasing the proportion of structural carbohydrates (NDF and ADF) in the feed leads to an increase of acetic production and reduction of the butyric acid production. Reduced level of non-structural carbohydrates results in lower production of VFA (Grochowska et al. 2012).

Iso-acids are produced as a result of catabolism of amino acids created by rumen microflora, their presence indicates the activity of proteolytic microorganisms (Del Bianco Benedeti et al. 2015). The highest and most favorable level of iso-acids in our results was observed in D4 group. The high amount of methane emitted causes energy loss for the animal which results in lower milk production. Observed in the D4 group reduced level of acetic acid to propionic acid reduces methane production (Stewart et al. 1997). Decreased methanogenesis in the rumen is a wanted phenomenon. Currently, there is a trend in agriculture for the introduction of feed additives and forage that reduce emission of methane (Yan et al. 2007). In our study, a slight decrease in the production of methane after the addition of roasted barley husks was observed. 
The ratio of non-glucogenic acids to glucogenic acids (NGR) influences milk production, energy balance and methane production (Morvay et al. 2011). In our research a clear increase in NGR was observed in a sample with the largest addition of roasted barley husks $(15 \%)$. Increase in the production of methane associated with the increase of NGR was not observed, however, it was reported in other studies (Dos Santos Pedreira et al. 2013). Glucogenic propionic acid is responsible for the deposition of fat in body tissues and together with non-glucogenic acids: acetic and butyric is the source for the synthesis of long chain fatty acids (LCFA) (Abrahamse 2009).

The authors of previous studies indicate that a greater share of the dry matter in the feed results in reduction of gases production, in particular methane. They conclude existence of a negative correlation between the protein content of feed and gas production in rumen in in vitro conditions (Getachew et al. 2004). In our study, we measured that the substrate of the control group was characterized by the highest level of dry matter and the lowest level of protein compared to the experimental groups (Table 2). In opposition to the results of other studies, our experiment did not result in an increase of methane production in experimental groups (D1, D2, D3, D4).

\section{CONCLUSIONS}

Maintaining the production of VFA on a physiologically correct level is a desirable effect of applying roasted barley husks. The activity of the symbiotic microorganisms involved in the fermentation has been impaired by the use of roasted barley husks additive. Most beneficial changes in the profile of VFA were observed in D3 and D4 groups. Using substrate with $15 \%$ $\mathrm{RBH}$ addition resulted with the highest growth of the $\mathrm{P}: \mathrm{B}$ indicator.

The obtained results indicate lack of negative impact of roasted barley husks on profile of in vitro cow's rumen fermentation. Stated changes in VFA profile, such as reduction of acetic acid level participation in groups D2 and D3 are beneficial. Results in this matter are promising as the roasted barley husks are a by-product of beer production and its usage has both economic and ecologic benefits. Obtained results in the in vitro study are the prerequisites to carry out in vivo experiments.

\section{REFERENCES}

Abdel Hameed A., Fedel E.L., Seed A.M., Salih A.M. 2013. Growth performance and rumen fermentation of lambs fed untreated or urea treated groundnut hull with different protein sources. J. Anim. Prod. Adv. 3, 86-96.

Abrahamse P.A., Vlaeminck B., Tamminga S., Dijkstra J. 2008. The effect of silage and concentrate type on intake behavior, rumen function, and milk production in dairy cows in early and late lactation. J. Dairy. Sci. 91, 4778-4792.

Abrahamse S. 2009. Feeding and grazing management for dairy cattle: Opportunities for improved production. DSc. Wageningen University, Netherlands.

Bell J.M., Keith M.O. 1988. Effects of barley hulls, dietary protein level and weight of pig on digestibility of canola meal fed to finishing pigs. Can. J. Anim. Sci. 68, 493.

Bhatta R., Tajima K., Kurihara M. 2006. Influence of temperature and pH on fermentation pattern and methane production in the rumen simulating fermenter (RUSITEC). Asian-Aust. J. Anim. Sci. 19, 376-380. 
Cabras I., Higgins D. 2016. Beer, brewing, and business history. Busin. Hist. 58, 609-624.

Cozzolino D., Degner S., Eglinton J.K. 2015. In situ study of water uptake by the seeds, endosperm and husk of barley using infrared spectroscopy. Spectrochimica Acta, Part A: Mol. Biomol. Spect. 150, 200-206.

Davis C.L., Grenawalt D.A., McCoy G.C. 1983. Feeding value of pressed Brewers' grains for lactating dairy cows. J. Dairy Sci. 66, 73-79.

Deepak K., Sangeeta G., Jana A.K. 2013. Thermal and Morphological Properties of Chemically Treated Barley Husk fibre. Int. J. Res. Mech. Eng. Tech. (IJRMET) 3, 2249-5762.

Del Bianco Benedeti P., Galoro da Silva L., Marostegan de Paula E., Shenkoru T., Marcondes M.I., Monteiro H.F. 2015. Effects of partial replacement of corn with glycerin on ruminal fermentation in a dual-flow continuous culture system. PLoS ONE 10, 0143201.

Dłużewski M. 2001. Technologia żywności. Podręcznik dla technikum. Warszawa, WSiP S.A., 271. [in Polish]

Dos Santos Pedreira M., Oliveira S.G. de, Primavesi O., Lima M.A. de, Frighetto R.T.S., Berchielli T.T. 2013. Methane emissions and estimates of ruminal fermentation parameters in beef cattle fed different dietary concentrate levels. R. Bras. Zootech. 42, 592-598.

Edmonson A.J., Lean I.J., Weaver L.D., Farver T., Webster G. 1989. A body condition scoring chart for holstein dairy-cows. J. Dairy Sci. 72, 68-78.

Getachew G., Robinson P.H., DePeters E.J., Taylor S.J. 2004. Relationships between chemical composition, dry matter degradation and in vitro gas production of several ruminant feeds. Anim. Feed Sci. Technol. 111, 57-71.

Grochowska S., Nowak W., Mikuła R., Kasprowicz-Potocka M. 2012. The effect of Saccharomyces cerevisiae on ruminal fermentation in sheep fed high- or low-NDF rations. J. Anim. Feed Sci. 21, 276-284.

Grove A.V., Hepton J., Hunt C.W. 2003. Chemical composition and ruminal fermentability of barley grain, hulls, and straw as affected by planting date, irrigation level, and variety. The Prof. Anim. Sci. 19, 273-280.

Gupta M., Abu-Ghannam N., Gallaghar E. 2010. Barley for brewing: Characteristic changes during malting, brewing and applications of its by-products. Compr. Rev. Food Sci. Food Safety 9, 318-328.

Heinhrisch J., Varga G. 1996. From feed to milk: Understanding rumen function. Part I: Background in basic nutrition of dairy cattle. The Pennsylvania State University, USA.

Ishiwaki N., Murayama H., Awayama H., Kanauchi O., Sato T. 2005. Development of high value uses of spent grain by fractionation technology. MBAA Tech. Quart. 37, 261-265.

Křižova L., Richter M., Třinacty J., Řiha J., Kumprechtova D. 2011. The effect of feeding live yeast cultures on ruminal $\mathrm{pH}$ and redox potential in dry cows as continuously measured by a new wireless device. Czech J. Anim. Sci. 56, 37-45.

McCarthy A., O'Callaghan Y., Piggott O., FitzGerald R., O'Brien N. 2012. Brewers spent grain; bioactivity of phenolic component, its role in animal nutrition and potential for incorporation in functional foods: a review. Proc. Nutrit. Soc. 72, 117-125.

McDougall E.I. 1948. Studies on ruminant saliva. 1. The composition and output of sheep's saliva. Biochem. J. 43, 99-109.

Moore K.J., Hatfield R.D. 1994. Carbohydrates and forage quality, in: Forage quality, evaluation, and utilization. Ed. G.C. Fahey, Jr. American Society of Agronomy, Crop Science Society of America, Madison, USA, 229.

Morvay Y., Bannink A., France J., Kebreab E., Dijkstra J. 2011. Evaluation of models to predict the stoichiometry of volatile fatty acid profiles in rumen fluid of lactating Holstein cows. J. Dairy. Sci. 94, 3063-3080.

Mussatto S.I., Dragone G., Roberto I.C. 2006. Brewers spent grain: generation, characteristics and potential applications. J. Cereal Sci. 43, 1-14. 
Okamoto H., Sato K., Yagi N., Inoue M., Yamasaki S., Ishida S., Shibata J. 2002. Development of production process of charcoal bricks from spent grain. Kagaku Kogaku Ronbunshu 28, 137-142.

Piva G., Belladonna S., Fusconi G., Sicbaldi F. 1993. Effects of yeast on dairy cow performance, ruminal fermentation, blood components, and milk manufacturing properties. J. Dairy. Sci. 76(9), 2717-2722.

Sato K., Yagi N., Okamoto K., Inoue M., Ajiri T., Shibata J. 2001. Physical property and burning property of spent grain charcoal. Shigen to Sozai $117,587-590$.

StatSoft, Inc. 2012. Electronic statistics textbook. Tulsa, StatSoft, http://www.statsoft.com/textbook/.

Stewart C.S., Flint H.J., Byrant M.P. 1997. The rumen bacteria, in: The rumen microbial ecosystem. Eds. P.N. Hobson, C.S. Stewart. 2nd ed. New York, USA, Blackie Academic and Professional, 10-55.

Urbaniak M., Błędzki A.K. 2015. Epoxy biocomposites reinforced with natural short fibres and microfibres from grain by-products. Inż. Mater. 36, 211-215.

Yan T., Mayne S., Porter M.G. 2006. Effects of dietary and animal factors on methane production in dairy cows offered grass silage-based diets. Int. Congr. Ser. 1293, 123-126.

Zanker G., Kepplinger W.L. 2002. The utilization of spent grains in the brewery integrated system. Montanuniversität Leoben Brauwelt 142, 1742-1747.

Zhou Y.W., McSweeney C.S., Wang J.K., Liu J.X. 2012. Effects of disodium fumarate on ruminal fermentation and microbial communities in sheep fed on high-forage diets. Animal 6, 815-823.

\title{
WPŁYW ZASTOSOWANIA PRAŻONYCH ŁUSEK JĘCZMIENIA, BĘDACYCH PRODUKTEM UBOCZNYM PRZEMYSŁU BROWARNIANEGO, NA PROCESY FERMENTACJI ŻWACZOWEJ KRÓW. BADANIA IN VITRO
}

\begin{abstract}
Streszczenie. Celem pracy była ocena wpływu zastosowania prażonych łusek jęczmienia $(\mathrm{RBH})$, będących produktem ubocznym przemysłu browarnianego, na procesy fermentacji żwaczowej, w warunkach in vitro. W badaniach użyto płyn żwaczowy pobrany od 9 krów mlecznych wybranych na podstawie analogów. Zwierzęta karmiono w systemie dawki wymieszanej całkowicie (TMR). Substraty do eksperymentu in vitro ustalono na podstawie dawki TMR. Substrat kontrolny zawierał tylko TMR. Substraty D1, D2, D3 zawierały TMR z dodatkiem odpowiednio: 5, 10 i 15\% suchej masy RBH. Substrat D4 zawierał tylko RBH. Próbki płynu żwacza inkubowano przez 8 godzin, w warunkach beztlenowych, w $39^{\circ} \mathrm{C}$. Pożądany efekt stosowania prażonych łusek jęczmienia zaobserwowano w grupach D3 i D4 zwiększyła się produkcja lotnych kwasów tłuszczowych (LKT). Kolejne pozytywne efekty odnotowano w grupach D2 i D4 - produkcja kwasu octowego zmniejszyła się do 7\%. W grupach eksperymentalnych zaobserwowano zmniejszone wytwarzanie metanu (do 10\%), co wskazuje na obniżenie strat energii przez zwierzęta. Najkorzystniejsze zmiany w profilu LKT i znaczny wzrost NGR odnotowano w próbkach z grupy D3. Ponieważ prażone łuski jęczmienia są produktem ubocznym warzenia piwa, ich stosowanie przynosi korzyści zarówno ekonomiczne, jak i ekologiczne. Pozytywne wyniki badania in vitro stanowią warunki wstępne do przeprowadzenia eksperymentu in vivo.
\end{abstract}

Słowa kluczowe: łuski jęczmienne, fermentacja mikrobiologiczna, żwacz, metan, lotne kwasy tłuszczowe. 
